\section{EJMBE 31,1}

\section{2}

Received 9 September 2020 Revised 31 March 2021 11 May 2021

Accepted 1 June 2021

\title{
Using the $Z$-score to analyze the financial soundness of insurance firms
}

\author{
Ignacio Moreno \\ Financial Economics and Accounting, Universidad Pablo de Olavide, Sevilla, Spain \\ Purificación Parrado-Martínez \\ Financial Economics and Accounting, Universidad de Jaén, Jaen, Spain, and \\ Antonio Trujillo-Ponce \\ Financial Economics and Accounting, Universidad Pablo de Olavide, Sevilla, Spain
}

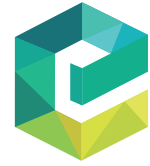

European Journal of Management and Business Economics Vol. 31 No. 1, 2022 pp. $22-39$

Emerald Publishing Limited e-ISSN: 2444-8494

p-ISSN: $2444-8451$

DOI 10.1108/EJMBE-09-2020-0261

\begin{abstract}
Purpose - Despite the sophisticated regulatory regime established in Solvency II, analysts should be able to consider other less complex indicators of the soundness of insurers. The $Z$-score measure, which has traditionally been used as a proxy of individual risk in the banking sector, may be a useful tool when applied in the insurance sector. However, different methods for calculating this indicator have been proposed in the literature. This paper compares six different $Z$-score approaches to examine which one best fits insurance companies. The authors use a final dataset of 183 firms (1,382 observations) operating in the Spanish insurance sector during the period 2010-2017.

Design/methodology/approach - In the first stage, the authors opt for a root mean squared error (RMSE) criterion to evaluate which of the various mean and SD estimates that are used to compute the $Z$-score best fits the data. In the second stage, the authors estimate and compare the explanatory power of the six $Z$-score measures that are considered by using an ordinary least squares (OLS) regression model. Finally, the authors report the results of the baseline equation using the system-GMM estimator developed by Arellano and Bover (1995) and Blundell and Bond (1998) for dynamic panel data models.

Findings - The authors find that the best formula for calculating the $Z$-score of insurance firms is the one that combines the current value of the return on assets (ROA) and capitalization with the SD of the returns calculated over the full sample period.

Research limitations/implications - The main limitation of the research is that it addresses only the Spanish insurance sector, and consequently, the implications of the findings must be framed in this institutional context. However, the authors think that the results could be extrapolated to other countries. Future research should consider including different countries and analyzing the usefulness of aggregated insurer-level $Z$-scores for macroprudential monitoring.

Practical implications - The $Z$-score may be a useful early warning indicator for microprudential supervision. In addition to being an indicator of the soundness of insurers simpler than those established in the current regulation, the information provided by this accounting-based measure may help analysts and investors obtain a better understanding of insurance firms' risk factors.
\end{abstract}

JEL Classification - G22, G28, G32, G33

(C) Ignacio Moreno, Purificación Parrado-Martínez and Antonio Trujillo-Ponce. Published in European Journal of Management and Business Economics. Published by Emerald Publishing Limited. This article is published under the Creative Commons Attribution (CC BY 4.0) licence. Anyone may reproduce, distribute, translate and create derivative works of this article (for both commercial and noncommercial purposes), subject to full attribution to the original publication and authors. The full terms of this licence may be seen at http://creativecommons.org/licences/by/4.0/legalcode

The authors are grateful to the participants of the 2019 Meeting of the Spanish Accounting and Business Administration Association (AECA), the two anonymous referees and the Editor for their valuable comments and suggestions. The authors also acknowledge the financial support of the Regional Government of Andalusia, Spain (Research Groups SEJ-289 and SEJ-555). The usual disclaimer applies.

On behalf of all authors, the corresponding author states that there is no conflict of interest. 
Originality/value - To the best of the authors' knowledge, this study is the first to examine and compare different approaches to calculating $Z$-scores in the insurance sector. The few available results on the predictive power of the $Z$-score are mixed and focus on the banking sector.

Keywords Insurance sector, $Z$-score, Economic crisis, Financial soundness, European financial system Paper type Research paper
The financial soundness of insurance firms

\section{Introduction}

The insurance industry plays a crucial role in the economy by allowing individuals and companies to transfer risk through insurance and reinsurance activities and thus enhances financial stability (Das et al., 2003). This industry, which contributes significantly to economic growth and notably impacts investors and stakeholders, has become an important pillar of the financial sector (Haiss and Sümegi, 2008). Although insurance companies have traditionally been considered less risky than banks because they are less exposed to liquidity risk (Caporale et al., 2017), the increasing interactions among the insurance sector, financial markets and other financial intermediaries, as well as financial innovations, globalization and the deregulation of the financial system, have made the operations of financial intermediaries over the last decades more complex and potentially riskier (Sharpe and Stadnik, 2007). While the contagion effects from the failure of firms in the insurance sector may not be as consequential as those in the banking industry, they have relevant potential to disrupt the financial system and negatively impact the economy (Das et al., 2003). Therefore, the soundness of insurance firms is of major importance not only for the welfare of the financial sector and various stakeholders (Pasiouras and Gaganis, 2013) but also for the stability of the economy as a whole.

Consequently, policy makers are working to upgrade regulatory and supervisory frameworks to reduce insolvency risk and promote confidence in the financial stability of the insurance sector. In this vein, European insurers have recently implemented Solvency II, a risk-based economic approach aimed at adopting solvency requirements that better reflect the risk of companies (Cummins et al., 2017). This new supervisory regime in the EU includes a risk-sensitivity requirement that is based on a prospective calculation to ensure accurate and timely interventions by the supervisor (the solvency capital requirement) [1]. Despite the sophisticated regulatory regime established in Solvency II, analysts should be able to consider other less complex indicators of the soundness of insurers.

The $Z$-score measure, which has traditionally been used as a proxy of individual risk for the banking sector (Boyd et al., 2006; Laeven and Levine, 2009; Lepetit and Strobel, 2013; Baselga-Pascual et al., 2015; Chiaramonte et al., 2015; Khan et al., 2017), may be a useful tool when applied in the insurance sector. The $Z$-score relates a firm's capital level to the variability in its return on assets (ROA), revealing how much variability in returns can be absorbed by capital without the firm becoming insolvent (Li et al., 2017). The popularity of the $Z$-score derives from its relative simplicity and the fact that it can be computed using accounting information alone. In contrast to market-based risk measures, this indicator is applicable when dealing with an extensive number of unlisted as well as listed companies (Chiaramonte et al., 2016).

Our research contributes to the body of knowledge by examining and comparing, for first time, different approaches to calculating the $Z$-score on a sample of insurance firms. The few available results on the predictive power of this indicator are mixed and focus on the banking sector (Lepetit and Strobel, 2013; Chiaramonte et al., 2016; Bongini et al., 2018). Our paper also adds to the literature on the factors that determine the risk of insurance companies. The $Z$ score, as a simple accounting-based measure, may help analysts and investors obtain a better understanding of risk factors in the insurance sector. Finally, we focus on the Spanish insurance sector, which is one of the largest in Europe (IMF, 2017). Specifically, Spain is 
EJMBE 31,1

among the top ten European countries in terms of gross premiums written and asset volume (EIOPA, 2017), and this country continues to lead in growth among the major Eurozone economies (MAPFRE, 2018). Although the implications of our findings must be framed in this institutional context, we think that our results could be extrapolated to other countries.

The rest of the paper is organized as follows. The next section presents the basics of the $Z$ score calculation. The third section describes the data and methodology. The fourth section analyzes the main results. The final section concludes the paper.

\section{Theoretical background and literature review}

\subsection{Measuring the financial soundness of insurance companies: the Z-score}

A broad strand of the literature has focused on the analysis of diverse measures of capitalization (i.e. the actual solvency margin, the required solvency margin, or the solvency ratio) to draw conclusions about the financial soundness of firms (e.g. Cummins and Nini, 2002; De Haan and Kakes, 2010; Rubio-Misas and Fernández-Moreno, 2017; Moreno et al., 2020; among others). Nevertheless, limiting the analysis to insurers' capitalization could be too restrictive, and a wider approach is necessary to examine the different factors that influence the financial soundness of an insurer (see, e.g. $\mathrm{Hu}$ and $\mathrm{Yu}, 2014$; Mankaï and Belgacem, 2016; Altuntas and Rauch, 2017; Cummins et al., 2017; Shim, 2017).

The $Z$-score can be considered an alternative measure of risk and thus a good indicator of the financial soundness of insurers that takes into account factors beyond capitalization or the particular event of bankruptcy [2]. Although the $Z$-score is traditionally used as an indicator of individual risk in the banking literature (Boyd et al., 2006; Laeven and Levine, 2009; Maechler et al., 2010; Cihák and Hesse, 2010; Lepetit and Strobel, 2013; Baselga-Pascual et al., 2015; Chiaramonte et al., 2015, 2016; Khan et al., 2017; among others), some recent studies have also used this measure to examine the financial soundness of insurance firms (see, e.g. Shim, 2011; Pasiouras and Gaganis, 2013; Altuntas and Rauch, 2017; Cummins et al., 2017; Shim, 2017; Alhassan and Biekpe, 2018; Gaganis et al., 2019, Pavić et al., 2019; Rubio-Misas, 2020). The Z-score may be a simple and effective predictor of insurer failure given the simplicity and transparency of its calculation (Plantin and Rochet, 2007) and because it can be computed for both unlisted and listed firms (Bongini et al., 2018).

This measure can be applied to insurers with different risk strategies (Čihák and Hesse, 2010; Pasiouras and Gaganis, 2013): an institution may have the same or higher Z-score than other insurers with lower capitalization if it has higher risk-adjusted returns. Nevertheless, the $Z$-score has some disadvantages to consider. First, as an accounting-based measure, its reliability depends on the quality of the underlying accounting and auditing framework, which is a serious concern in less-developed countries. Additionally, as firms may smooth their accounting data over time, the $Z$-score may offer an excessively positive assessment of insolvency risk (Laeven and Majnoni, 2003). Second, as pointed out by Cihák (2007), the Zscore evaluates each firm separately, potentially overlooking the risk that distress in one financial institution may cause losses to other financial institutions in the system. In the same vein, Bongini et al. (2018) conclude that the $Z$-score has limitations in the macroprudential monitoring framework for detecting banking crises, at least in emerging economies, because accounting-based measures do not capture all of the dimensions of risk, such as contagion and interconnectedness (i.e. systemic risk) [3], [4].

\subsection{Different approaches to calculating the Z-score}

As stated previously, the basic principle behind the $Z$-score is to relate the capital ratio to the variability in the ROA so that one can know how much variability in returns can be absorbed by capital without the firm becoming insolvent (Li et al., 2017): 


$$
Z s=\frac{\mathrm{ROA}+\mathrm{Eq} / \mathrm{TA}}{\sigma \mathrm{ROA}}
$$

where $\mathrm{Eq} / \mathrm{TA}$ denotes the equity-to-total assets ratio and $\sigma \mathrm{ROA}$ represents the standard deviation (SD) of the ROA.

Default is expected to occur when losses consume capital (i.e. when ROA $+\mathrm{Eq} / \mathrm{TA} \leq 0$ or, equivalently, when $\mathrm{ROA} \leq-\mathrm{Eq} / \mathrm{TA}$ ). Then, if we assume that $\mathrm{ROA}$ is a random variable, the $Z$-score represents the number of standard deviations between the expected value of the ROA, $E(\mathrm{ROA})$ and the negative values of $\mathrm{ROA}, \mathrm{ROA}=-\mathrm{Eq} / \mathrm{TA}$, that would result in insolvency (Hannan and Hanweck, 1988). In other words, it indicates the number of standard deviations that the ROA would have to fall to deplete equity and force a failure. As in the banking sector, equity serves as a buffer against unforeseen losses and is critical for an insurer's ability to meet its obligations (Cummins et al., 2017). Hannan and Hanweck (1988) show that the Chebyshev inequality for any symmetric distribution allows us to assume the following upper bound on the probability of default (PD):

$$
\mathrm{PD} \leq \frac{1}{2}\left(\frac{\sigma \mathrm{ROA}}{E(\mathrm{ROA})+\mathrm{Eq} / \mathrm{TA}}\right)^{2}=\frac{1}{2}(Z s)^{-2}
$$

Therefore, a higher $Z$-score is associated with a higher distance to default (a lower probability of insolvency). It does not require strong assumptions about the distribution of ROA (see, e.g. Strobel, 2011), which represents an especially attractive advantage from a practitioner's point of view.

The literature reports different approaches to calculating this measure. The most basic formulation defines the $Z$-score as the sum of the values in the current period $t$ of the firm's $\mathrm{ROA}\left(\mathrm{ROA}_{t}\right)$ and equity-to-total assets ratio $\left(\mathrm{Eq} / \mathrm{TA}{ }_{t}\right)$ divided by the $\mathrm{SD}$ of ROA calculated with data from the current year $(t)$ and the two previous years, i.e. $t-1$ and $t-2\left(\sigma \mathrm{ROA}_{3}\right)$ (Pasiouras and Gaganis, 2013; Chiaramonte et al., 2016; Cummins et al., 2017) [5]:

$$
Z s 1_{t}=\frac{\mathrm{ROA}_{t}+\mathrm{Eq} / \mathrm{TA}_{t}}{\sigma \mathrm{ROA}_{3}\left(\mathrm{ROA}_{t}, \mathrm{ROA}_{t-1}, \mathrm{ROA}_{t-2}\right)}
$$

Delis and Staikouras (2011) and Baselga-Pascual et al. (2015) derive a $Z$-score measure (Zs2) that uses data from the two previous years to calculate $\sigma \mathrm{ROA}$ at time $t\left(\sigma \mathrm{ROA}_{2}\right)$ :

$$
Z s 2_{t}=\frac{\mathrm{ROA}_{t}+\mathrm{Eq} / \mathrm{TA}_{t}}{\sigma \mathrm{ROA}_{2}\left(\mathrm{ROA}_{t-1}, \mathrm{ROA}_{t-2}\right)}
$$

Maechler et al. (2010) and Chiaramonte et al. (2016) compute the $Z$-score as the sum of the three-year moving average of $\mathrm{ROA}\left(\mathrm{ROA}_{\mu 3}\right)$ and the three-year moving average of the equityto-total assets ratio $\left(\mathrm{Eq} / \mathrm{TA}_{\mu 3}\right)$ divided by $\sigma \mathrm{ROA}_{3}[6]$ :

$$
Z s 3_{t}=\frac{\mathrm{ROA}_{\mu 3}\left(\mathrm{ROA}_{t}, \mathrm{ROA}_{t-1}, \mathrm{ROA}_{t-2}\right)+\mathrm{Eq} / \mathrm{TA}_{\mu 3}\left(\mathrm{Eq} / \mathrm{TA}_{t}, \mathrm{Eq} / \mathrm{TA}_{t-1}, \mathrm{Eq} / \mathrm{TA}_{t-2}\right)}{\sigma \mathrm{ROA}_{3}\left(\mathrm{ROA}_{t}, \mathrm{ROA}_{t-1}, \mathrm{ROA}_{t-2}\right)}
$$

Yeyati and Micco (2007) compute the $Z$-scores for each firm and year combining $\mathrm{ROA}_{\mu 3}$ with $\mathrm{Eq} / \mathrm{TA}_{t}$ and $\sigma \mathrm{ROA}_{3}$ :

$$
Z s 4_{t}=\frac{\mathrm{ROA}_{\mu 3}\left(\mathrm{ROA}_{t}, \mathrm{ROA}_{t-1}, \mathrm{ROA}_{t-2}\right)+\mathrm{Eq} / \mathrm{TA}_{t}}{\sigma \mathrm{ROA}_{3}\left(\mathrm{ROA}_{t}, \mathrm{ROA}_{t-1}, \mathrm{ROA}_{t-2}\right)}
$$

The financial soundness of insurance firms 
EJMBE 31,1

\section{6}

Boyd et al. (2006) and Chiaramonte et al. (2016) calculate the $Z$-score as the sum of $\mathrm{ROA}_{t}$ and $\mathrm{Eq} / \mathrm{TA}_{\mu 3}$ divided by $\sigma \mathrm{ROA}_{3}$ :

$$
Z s 5_{t}=\frac{\mathrm{ROA}_{t}+\mathrm{Eq} / \mathrm{TA}_{\mu 3}\left(\mathrm{Eq} / \mathrm{TA}_{t}, \mathrm{Eq} / \mathrm{TA}_{t-1}, \mathrm{Eq} / \mathrm{TA}_{t-2}\right)}{\sigma \mathrm{ROA}_{3}\left(\mathrm{ROA}_{t}, \mathrm{ROA}_{t-1}, \mathrm{ROA}_{t-2}\right)}
$$

Finally, Beck and Laeven (2006) and Hesse and Čihák (2007) estimate a Z-score measure that combines $\mathrm{ROA}_{t}$ and $\mathrm{Eq} / \mathrm{TA}_{t}$ with the $\mathrm{SD}$ of ROA calculated over the full period $\left(\sigma \mathrm{ROA}_{T}\right)$ :

$$
Z s 6_{t}=\frac{\mathrm{ROA}_{t}+\mathrm{Eq} / \mathrm{TA}_{t}}{\sigma \mathrm{ROA}_{T}\left(\mathrm{ROA}_{1}, \mathrm{ROA}_{2}, \ldots, \mathrm{ROA}_{T}\right)}
$$

\section{Data and methodology}

\subsection{Sample}

Our sample includes most of the insurance companies operating in Spain from 2008-2017. Data were obtained from the database maintained by the Spanish regulatory authority, the Directorate General of Insurance and Pension Funds (Dirección General de Seguros y Fondos de Pensiones) (DGSFP), an administrative body within the Ministry of Economy and Business [7]. However, as some of the components of the $Z$-score employ data from up to two years prior to the calculation date (i.e. $t-2, t-1$ ), this reduces our time span to the period 2010-2017 [8]. In addition, we do not consider social benefit institutions and reinsurance specialists because they have singular characteristics that may distort our analysis. We use unconsolidated financial statements, thereby reducing the possibility of introducing aggregation bias into the results. Merged insurers are considered to be separate firms before the merger and a single company afterward. Finally, we remove observations with abnormal ratios or extreme values from the sample, ensuring that the analysis is not affected by potential measurement error or misreporting. After applying these filters, we obtain a final dataset consisting of an unbalanced panel with 183 insurers and 1,382 observations (see Table 1). We have a minimum of five consecutive observations for each company, with $77.60 \%$ of the insurers being observed over the entire period.

\subsection{Choosing the best Z-score approach}

We explore which of the different methods for computing the $Z$-score reported in section 2.2 is best when using actual data. Following a procedure similar to that employed by Lepetit and Strobel (2013) for the banking sector, we opt for a root mean squared error (RMSE) criterion to evaluate which estimator best fits the data by minimizing the weighted average RMSE of the $N$ insurers $j$ given by

\begin{tabular}{lccc}
\hline Year & Mutual insurers & Stock insurers & \\
\hline 2010 & 29 & 146 & Total \\
2011 & 29 & 150 & 175 \\
2012 & 30 & 152 & 179 \\
2013 & 30 & 153 & 182 \\
2014 & 30 & 153 & 183 \\
2015 & 30 & 141 & 183 \\
2016 & 29 & 131 & 171 \\
2017 & 26 & 123 & 160 \\
& 233 & 1,149 & 149 \\
& 26 & & 1,382
\end{tabular}

Table 1.

Number of observations in the final sample 


$$
\mathrm{RMSE}=\sum_{j=1}^{N} \frac{T_{j}}{\sum_{j=1}^{N} T_{j}} \sqrt{\frac{1}{T_{j}} \sum_{t=1}^{T_{j}}\left(x_{j, t}-\mu_{x, j, t-1}^{\mathrm{est}}\right)^{2}}
$$

The financial soundness of insurance firms

where $x$ and $\mu_{x}^{\text {est }}$ are, respectively, the realized and predicted values of the different variables that are used to compute the time-varying $Z$-score measures $Z s 1$ to $Z s 6$ (i.e. $\mathrm{ROA}_{t}, \mathrm{ROA}_{\mu 3}$, Eq/ $\mathrm{TA}_{t}, \mathrm{Eq} / \mathrm{TA}_{\mu 3}, \sigma \mathrm{ROA}_{2}, \sigma \mathrm{ROA}_{3}$ and $\left.\sigma \mathrm{ROA}_{T}\right)$. All these equations are calculated for the full sample for each period $t \in\{1 \ldots T\}$.

The RMSE is the square root of the mean of the squares of all of the errors, and it is considered to be an excellent error metric for numerical predictions. Naturally, a lower parameter outcome is preferable.

Moreover, we estimate and compare the explanatory power of the following multivariate empirical model for the Spanish insurance sector:

$$
Y_{i, t}=\alpha+\beta \cdot \mathrm{FS}_{i, t}+\theta \cdot D_{i, t}+\gamma \cdot I_{t}+\delta \cdot M_{t}+\varepsilon_{i, t}
$$

where $Y$ denotes the different approaches to estimating the $Z$-score (in logarithmic form) for insurer $i$ (i.e. $Z s 1$ to $Z s 6$ ) in year $t$; [9] $\mathrm{FS}_{i, t}$ denotes a set of firm-specific accounting variables that the literature has recognized as good predictors of insurer risk, $D_{i, t}$ represents two dummy variables that control for the specialization (life versus nonlife) and the organizational form (mutual versus stock company) of the insurer, $I_{t}$ represents a variable that accounts for the possible effect of industry concentrations on insurer risk, and $M_{t}$ denotes a set of year dummy variables that account for macroeconomic conditions and timespecific effects. In the regression above, $\alpha$ is the intercept term, and $\beta, \gamma, \theta$ and $\delta$ are vectors of coefficient estimates. Last, $\varepsilon_{i, t}$ is the disturbance term.

Table 2 summarizes the explanatory variables that are included in the present study and their expected $Z$-score signs - remember that the $Z$-score (i.e. the distance to default) operates in the opposite direction of insurer risk: the higher the $Z$-score is, the lower the risk.

We use the natural logarithm of total assets to account for the effect of size on risk and expect a positive relationship between size and the $Z$-score, as financially distressed insurers are typically small in size (Sharpe and Stadnik, 2007). To examine the influence of profitability on insurer risk, we divide profits after tax by total assets (i.e. ROA). Sharpe and Stadnik (2007) conclude that insurers with low ROA are at higher risk of failure. In the same vein, Caporale et al. (2017) report that highly profitable insurers are less likely to become insolvent because they manage their expenses effectively and can set competitive premium rates. We include the equity-to-total assets ratio to control for the effect of capitalization on insurer risk. When measuring default risk, the capital used to cover the insurance business is a key factor. Insurance firms should hold enough capital to cover the policies they underwrite (Caporale et al., 2017). Altuntas and Rauch (2017) find that higher levels of capitalization are associated with higher levels of financial stability in the insurance sector. To account for the effect of reinsurance on the $Z$-score models, we use the ratio of reinsurance premiums paid to total premiums earned. Reinsurance allows insurers to transfer part of their risk to third parties and results in more predictable future losses, thereby reducing the probability of default (Shiu, 2011; Caporale et al., 2017). Consequently, we expect a positive relationship between the use of reinsurance by the insurer and the $Z$-score. We choose the share of equity securities in total assets to measure the effect of investment risk on insurer risk and expect a negative relationship between portfolio risk and our distance-to-default measures. Similar to Ho et al. (2013) and Altuntas and Rauch (2017), we proxy underwriting risk with the SD of the loss ratio, defined as incurred losses divided by premiums earned net of reinsurance, over the sample period. As stated by Cummins and Sommer (1996), underwriting risk refers to the risk that loss payments will be greater than the expected losses allowed for in the premiums 


\section{EJMBE 31,1}

Table 2.

Explanatory variables and their expected signs in the $Z$-score regressions

\begin{tabular}{|c|c|c|c|c|}
\hline $\begin{array}{l}\text { Explanatory } \\
\text { variable }\end{array}$ & Definition & $\begin{array}{l}\text { Expected } \\
\text { sign }\end{array}$ & Data source & References \\
\hline Size & Natural log of total assets & + & $\begin{array}{l}\text { Authors' } \\
\text { calculation } \\
\text { using DGSFP } \\
\text { data }\end{array}$ & $\begin{array}{l}\text { Chen and Wong } \\
\text { (2004), Pasiouras and } \\
\text { Gaganis (2013), Shim } \\
\text { (2017) }\end{array}$ \\
\hline Profitability & $\begin{array}{l}\text { Profits after tax divided by total } \\
\text { assets }\end{array}$ & + & $\begin{array}{l}\text { Authors' } \\
\text { calculation } \\
\text { using DGSFP } \\
\text { data }\end{array}$ & $\begin{array}{l}\text { Sharpe and Stadnik } \\
\text { (2007), Caporale et al. } \\
(2017)\end{array}$ \\
\hline Capitalization & Equity-to-total assets ratio & + & $\begin{array}{l}\text { Authors' } \\
\text { calculation } \\
\text { using DGSFP } \\
\text { data }\end{array}$ & $\begin{array}{l}\text { Shim (2011), Altuntas } \\
\text { and Rauch (2017) }\end{array}$ \\
\hline Reinsurance & $\begin{array}{l}\text { Reinsurance premiums paid } \\
\text { divided by total premiums } \\
\text { earned }\end{array}$ & + & $\begin{array}{l}\text { Authors' } \\
\text { calculation } \\
\text { using DGSFP } \\
\text { data }\end{array}$ & $\begin{array}{l}\text { Ho et al. (2013), } \\
\text { Mankaï and Belgacem } \\
\text { (2016), Caporale et al. } \\
\text { (2017) }\end{array}$ \\
\hline Portfolio risk & $\begin{array}{l}\text { Equity securities in the asset } \\
\text { portfolio divided by total assets }\end{array}$ & - & $\begin{array}{l}\text { Authors' } \\
\text { calculation } \\
\text { using DGSFP } \\
\text { data }\end{array}$ & Cummins et al. (2017) \\
\hline $\begin{array}{l}\text { Underwriting } \\
\text { risk }\end{array}$ & $\begin{array}{l}\text { SD of the loss ratio over the } \\
\text { sample period, defined as } \\
\text { incurred losses divided by } \\
\text { premiums earned, net of } \\
\text { reinsurance }\end{array}$ & - & $\begin{array}{l}\text { Authors' } \\
\text { calculation } \\
\text { using DGSFP } \\
\text { data }\end{array}$ & $\begin{array}{l}\text { Altuntas and Rauch } \\
\text { (2017) }\end{array}$ \\
\hline $\begin{array}{l}\text { Long-tailed } \\
\text { business }\end{array}$ & $\begin{array}{l}\text { Technical provisions (loss } \\
\text { reserves) divided by incurred } \\
\text { losses }\end{array}$ & - & $\begin{array}{l}\text { Authors' } \\
\text { calculation } \\
\text { using DGSFP } \\
\text { data }\end{array}$ & $\begin{array}{l}\text { Sharpe and Stadnik } \\
\text { (2007), de Haan and } \\
\text { Kakes (2010), Ho et al. } \\
\text { (2013) }\end{array}$ \\
\hline Mutual & $\begin{array}{l}\text { Dummy variable that takes on a } \\
\text { value of } 1 \text { for mutual companies } \\
\text { and } 0 \text { otherwise }\end{array}$ & + & $\begin{array}{l}\text { Authors' } \\
\text { calculation } \\
\text { using DGSFP } \\
\text { data }\end{array}$ & $\begin{array}{l}\text { Pasiouras and } \\
\text { Gaganis (2013), Shim } \\
\text { (2017), Altuntas and } \\
\text { Rauch (2017) }\end{array}$ \\
\hline Life insurance & $\begin{array}{l}\text { Dummy variable that takes on a } \\
\text { value of } 1 \text { if life technical } \\
\text { provisions are at least } 80 \% \text { of } \\
\text { overall technical provisions and } \\
0 \text { otherwise }\end{array}$ & + & $\begin{array}{l}\text { Authors' } \\
\text { calculation } \\
\text { using DGSFP } \\
\text { data }\end{array}$ & $\begin{array}{l}\text { Chen and Wong } \\
\text { (2004), Pasiouras and } \\
\text { Gaganis (2013), Eling } \\
\text { and Marek (2013) }\end{array}$ \\
\hline $\begin{array}{l}\text { Industry } \\
\text { concentration }\end{array}$ & $\begin{array}{l}\text { Herfindahl-Hirschman index, } \\
\text { calculated as the sum of the } \\
\text { squares of all insurance } \\
\text { companies' market shares in } \\
\text { terms of premiums written (as a } \\
\text { percentage) }\end{array}$ & \pm & MAPFRE (2018) & $\begin{array}{l}\text { Ho et al. (2013), } \\
\text { Caporale et al. (2017) }\end{array}$ \\
\hline Year dummies & $\begin{array}{l}\text { Dummy variables used to } \\
\text { control for macroeconomic } \\
\text { conditions and time-specific } \\
\text { effects }\end{array}$ & & & \\
\hline
\end{tabular}

charged to policyholders. We thus anticipate a negative association between underwriting risk and the $Z$-score. To account for the effect of the time lag between the issuance and payment of claims on insurer risk, we use the ratio of technical provisions (i.e. loss reserves) over incurred losses. Long-tail lines of insurance (i.e. insurance with a longer time lag between 
policy issuance and the payment of claims) may have a negative effect on insurer solvency because long-tail lines tend to generate less income from underwriting than shorter-tail lines (De Haan and Kakes, 2010). We therefore expect this variable to have a negative effect on the $Z$-score.

We account for the ownership structure of the firm and insurer specialization using two dummy variables [10]. Altuntas and Rauch (2017) report that mutual insurance firms have higher $Z$-score levels because their future cash flows are less risky. In addition, these authors state that the incentive to increase risk after issuing policies should be much lower for mutual insurers than for stock insurers due to their organizational structure. We also expect a positive coefficient for the dummy that identifies life insurance companies, as nonlife insurers are considered riskier than life insurance companies because they operate as "risk takers" (Chen and Wong, 2004). In the same vein, Gründl et al. (2016) consider nonlife insurers to be riskier because of the uncertainty of claim payments and the difficulty in predicting threats.

Finally, we measure industry concentration using the Herfindahl-Hirschman index. There is no consensus regarding the expected relationship between industry concentration and insurer risk. The "concentration-stability" view states that because large firms are likely to earn more profits due to their market power, a concentrated industry is more stable. Therefore, this view favors greater values for the $Z$-score. However, the "concentration-fragility" view affirms that the too-big-to-fail protective mechanism may lead to excessive risk-taking by managers (Moreno et al., 2020), resulting in lower values of the $Z$-score. In this vein, Shim (2017) shows that a higher market concentration is associated with decreased financial stability in the US property-liability insurance industry.

\section{Results}

\subsection{Analysis of the different Z-score measures}

Table 3 reports some descriptive statistics for the six different time-varying $Z$-score measures. The results for $Z s 1, Z s 3, Z s 4$ and $Z s 5$ are very similar, with means (as calculated per insurer) in the interval of 3.693-3.787. Zs2 presents a higher mean and SD. Zs6, on the other hand, has results that are very different from those of the other measures, with average means and standard deviations in a lower range as well as a smaller average coefficient of variation (0.320). We also observe that mutual insurance companies present higher mean values than stock companies for each of the six $Z$-score measures considered. Similarly, we find differences in these measures between life and nonlife specialized insurers, although in this case, they are not as large as in the former. Finally, the lowest average $Z$-score is reported in 2010, whereas the highest $Z$-score mean values are found in 2016 and 2017, which is in line with the improvements in the Spanish economy.

Table 4 presents the average correlation coefficients of our six different $Z$-score measures, confirming the existence of three clusters: $Z s 1, Z s 3, Z s 4$ and $Z s 5$ have correlation coefficients close to 1 , whereas the coefficients for $Z s 2$ and $Z s 6$ are much lower.

Table 5 shows the results of the weighted average RMSE for each of the components of the $Z$-scores considered in the current study (i.e. $Z s 1-Z s 6$ ), indicating that $Z s 6$ is the $Z$-score measure that best fits the data. Therefore, according to this criterion, the best way to calculate the $Z$-score is using the values of ROA and Eq/TA in current period $t$ together with the SD of ROA calculated over the full sample, as proposed by Beck and Laeven (2006) and Hesse and Čihák (2007).

In Table 6, we estimate and compare the explanatory power of the six $Z$-score measures considered. First, however, we perform a multicollinearity analysis for the previously selected independent variables (see Table 7). We confirm that collinearity is
The financial soundness of insurance firms 


\section{EJMBE 31,1}

30

\begin{tabular}{|c|c|c|c|c|c|c|}
\hline & $Z s 1$ & $Z s 2$ & $Z s 3$ & $Z s 4$ & $Z s 5$ & $Z s 6$ \\
\hline \multicolumn{7}{|c|}{ Full sample } \\
\hline Mean & 3.787 & 4.232 & 3.772 & 3.780 & 3.693 & 3.085 \\
\hline SD & 1.290 & 1.594 & 1.297 & 1.307 & 1.268 & 0.995 \\
\hline Min & -2.642 & -1.967 & -2.759 & -1.967 & -0.389 & -2.843 \\
\hline Max & 9.817 & 11.927 & 9.833 & 9.817 & 9.825 & 8.168 \\
\hline \multicolumn{7}{|c|}{ Mutual } \\
\hline Mean & 4.329 & 4.785 & 4.307 & 4.327 & 4.282 & 3.517 \\
\hline SD & 1.255 & 1.488 & 1.252 & 1.258 & 1.240 & 0.927 \\
\hline \multicolumn{7}{|c|}{ Stock companies } \\
\hline Mean & 3.677 & 4.120 & 3.663 & 3.669 & 3.573 & 2.998 \\
\hline SD & 1.269 & 1.593 & 1.280 & 1.290 & 1.241 & 0.985 \\
\hline \multicolumn{7}{|c|}{ Nonlife specialized insurers } \\
\hline Mean & 3.786 & 4.200 & 3.768 & 3.776 & 3.651 & 3.059 \\
\hline SD & 1.277 & 1.548 & 1.295 & 1.303 & 1.334 & 1.143 \\
\hline \multicolumn{7}{|c|}{ Life specialized insurers } \\
\hline Mean & 3.790 & 4.319 & 3.781 & 3.789 & 3.708 & 3.095 \\
\hline SD & 1.323 & 1.710 & 1.306 & 1.320 & 1.243 & 0.933 \\
\hline \multicolumn{7}{|l|}{2010} \\
\hline Mean & 3.585 & 4.004 & 3.610 & 3.598 & 3.521 & 3.007 \\
\hline SD & 1.342 & 1.662 & 1.246 & 1.274 & 1.233 & 1.070 \\
\hline \multicolumn{7}{|l|}{2011} \\
\hline Mean & 3.791 & 4.235 & 3.794 & 3.781 & 3.707 & 3.032 \\
\hline SD & 1.311 & 1.588 & 1.302 & 1.340 & 1.283 & 0.972 \\
\hline \multicolumn{7}{|l|}{2012} \\
\hline Mean & 3.759 & 4.258 & 3.731 & 3.754 & 3.659 & 3.055 \\
\hline SD & 1.392 & 1.748 & 1.391 & 1.399 & 1.330 & 1.009 \\
\hline \multicolumn{7}{|l|}{2013} \\
\hline Mean & 3.751 & 4.277 & 3.696 & 3.724 & 3.614 & 3.108 \\
\hline SD & 1.304 & 1.648 & 1.346 & 1.375 & 1.314 & 0.974 \\
\hline \multicolumn{7}{|l|}{2014} \\
\hline Mean & 3.772 & 4.077 & 3.753 & 3.766 & 3.670 & 3.116 \\
\hline SD & 1.197 & 1.444 & 1.244 & 1.228 & 1.229 & 0.926 \\
\hline \multicolumn{7}{|l|}{2015} \\
\hline Mean & 3.768 & 4.226 & 3.758 & 3.766 & 3.680 & 3.110 \\
\hline SD & 1.197 & 1.498 & 1.191 & 1.214 & 1.180 & 0.999 \\
\hline \multicolumn{7}{|l|}{2016} \\
\hline Mean & 3.939 & 4.352 & 3.929 & 3.933 & 3.854 & 3.131 \\
\hline SD & 1.262 & 1.585 & 1.267 & 1.282 & 1.248 & 1.017 \\
\hline \multicolumn{7}{|l|}{2017} \\
\hline Mean & 3.975 & 4.481 & 3.946 & 3.957 & 3.882 & 3.136 \\
\hline SD & 1.282 & 1.532 & 1.375 & 1.323 & 1.309 & 1.0 \\
\hline
\end{tabular}

Note(s): This table reports descriptive statistics for six different $Z$-score measures. $Z s 1$ is defined in Table 3. Equation [3], Zs2 is defined in Equation [4], Zs3 is defined in Equation [5], Zs4 is defined in Equation [6], Zs5 is Descriptive statistics of defined in Equation [7], and Zs6 is defined in Equation [8]. All of these measures are calculated in logarithms. the different $Z$-score Our final dataset comprises 183 insurers (1,382 observations) operating in the Spanish insurance sector during metrics the period 2010-2017 


\begin{tabular}{|c|c|c|c|c|c|c|c|}
\hline & $Z s 1$ & $Z s 2$ & $Z s 3$ & $Z s 4$ & $Z s 5$ & $Z s 6$ & ncl \\
\hline$Z s 1$ & 1 & & & & & & insuranc \\
\hline$Z s 2$ & $0.7853^{* * * *}$ & 1 & & & & & \\
\hline Zs3 & $0.9863^{*}$ & $0.7756 *$ & 1 & & & & \\
\hline$Z s 4$ & 0.994 & 0.7825 & $0.9928 * * *$ & 1 & & & \\
\hline Zs5 & 0.9821 & 0.768 & 0.9910 & 0.9841 & 1 & & \\
\hline$Z s 6$ & $0.6885^{* * *}$ & $0.5398 * * *$ & $0.6711^{* * *}$ & $0.6831^{* * * *}$ & $0.6609 * * *$ & 1 & 1 \\
\hline \multicolumn{7}{|c|}{$\begin{array}{l}\text { Note(s): This table reports the pairwise correlation coefficients for six different } Z \text {-score measures. } Z s 1 \text { is } \\
\text { defined in Equation [3], Zs2 is defined in Equation [4], Zs3 is defined in Equation [5], Zs4 is defined in } \\
\text { Equation [6], Zs5 is defined in Equation [7], and } Z s 6 \text { is defined in Equation [8]. All of these measures are } \\
\text { calculated in logarithms. Our final dataset comprises } 183 \text { insurers (1,382 observations) operating in the Spanish } \\
\text { insurance sector during the period } 2010-2017 \text {. ***indicates significance at the } 1 \text { percent level }\end{array}$} & $\begin{array}{r}\text { Correlation coeffi } \\
\text { for the different } Z \\
\mathrm{~m}\end{array}$ \\
\hline
\end{tabular}

\begin{tabular}{lccccccc}
\hline$Z$-score & $\mathrm{ROA}_{t}$ & $\mathrm{ROA}_{\mu 3}$ & $\mathrm{Eq} / \mathrm{TA} t_{t}$ & $\mathrm{Eq} / \mathrm{TA}_{\mu 3}$ & $\sigma \mathrm{ROA}_{2}$ & $\sigma \mathrm{ROA}_{3}$ & $\sigma \mathrm{ROA}_{T}$ \\
\hline$Z s 1$ & 1.2781 & & 1.2423 & & & 1.0464 & \\
$Z s 2$ & 1.5843 & & 1.5630 & & 1.3402 & & \\
$Z s 3$ & & 1.2702 & & 1.2530 & & 1.0219 & \\
$Z s 4$ & 1.2775 & 1.2599 & & & 1.0297 & \\
$Z s 5$ & 1.2682 & & & 1.2134 & & 1.0484 & 0.8203 \\
$Z s 6$ & 0.9729 & & 0.9174 & & & &
\end{tabular}

Note(s): This table reports the average root mean squared error (RMSE) for the components of the different $Z$ score approaches. Our final dataset comprises 183 insurers (1,382 observations) operating in the Spanish insurance sector during the period 2010-2017. Zs1 is defined in Equation [3], Zs2 is defined in Equation [4], Zs3 is defined in Equation [5], Zs4 is defined in Equation [6], Zs5 is defined in Equation [7], and $Z s 6$ is defined in Equation [8]. $\mathrm{ROA}_{t}$ is the value of ROA in year $t ; R O \mathrm{~A}_{\mu 3}$ is the three-year moving average of $\mathrm{ROA}$. Eq/TA $/$ is the value of the equity-to-total assets ratio in year $t ; \mathrm{Eq} / \mathrm{TA}_{\mu 3}$ is the three-year moving average of $\mathrm{Eq} / \mathrm{TA} . \sigma \mathrm{ROA}_{2}$ is the two-year moving $\mathrm{SD}$ of ROA, $\sigma \mathrm{ROA}_{3}$ is the three-year moving $\mathrm{SD}$ of ROA, and $\sigma \mathrm{ROA}_{T}$ is the $\mathrm{SD}$ of ROA calculated over the whole period. The minimum average RMSE is highlighted in Italic

Table 5.

Root mean squared error for the components of the different $Z$-score approaches

not a problem by calculating the variance inflation factor (VIF); the calculated value for this factor is less than 4 (and close to 1) for most of the variables [11]. The regression model that uses Zs6 presents the highest explanatory power, with values for the adjusted $R^{2}$ slightly higher than $30 \%$. The rest of the models exhibit values close to $20 \%$, except for $Z s 2$, for which the adjusted $R^{2}$ falls to $12 \%$. Therefore, we confirm that the $Z s 6$ model is the best option for explaining insurer risk, in accordance with the results reported by the RMSE criterion [12].

\subsection{Analysis of the determinants of insurer risk}

Because some of the firm-specific factors that influence insurer risk may be endogenous (e.g. insurers might need to increase their capital ratio if they become riskier) and others are difficult to measure or identify in an equation (e.g. managerial ability), in Table 8, we report the results of our baseline equation using the system-GMM estimator developed by Arellano and Bover (1995) and Blundell and Bond (1998) for dynamic panel data models. The persistence of risk has been well documented in the banking literature (e.g. Baselga-Pascual et al., 2015). We are able to use the system-GMM method because we have information on all of the analyzed variables for at least five consecutive years for each insurer [13]. As proposed 


\section{EJMBE 31,1}

Table 6.

Comparative analysis of the $Z$-score models

\begin{tabular}{|c|c|c|c|c|c|c|}
\hline Variables & $\begin{array}{l}(1) \\
Z s 1\end{array}$ & $\begin{array}{l}(2) \\
Z s 2\end{array}$ & $\begin{array}{l}(3) \\
Z s 3 \\
\end{array}$ & $\begin{array}{l}(4) \\
Z s 4\end{array}$ & $\begin{array}{l}(5) \\
Z s 5\end{array}$ & $\begin{array}{l}(6) \\
Z s 6\end{array}$ \\
\hline Size & $\begin{array}{c}0.153 * * * \\
(0.039)\end{array}$ & $\begin{array}{c}0.157 * * * * \\
(0.044)\end{array}$ & $\begin{array}{c}0.139 * * * * \\
(0.039)\end{array}$ & $\begin{array}{c}0.155^{* * * *} \\
(0.040)\end{array}$ & $\begin{array}{c}0.128 * * * * \\
(0.038)\end{array}$ & $\begin{array}{c}0.145^{* * * *} \\
(0.039)\end{array}$ \\
\hline Profitability & $\begin{array}{c}3.388^{* * *} \\
(1.661)\end{array}$ & $\begin{array}{c}3.906^{* * *} \\
(1.661)\end{array}$ & $\begin{array}{c}2.642 \\
(1.813)\end{array}$ & $\begin{array}{l}3.213^{*} \\
(1.764)\end{array}$ & $\begin{array}{c}0.189 \\
(1.436)\end{array}$ & $\begin{array}{c}3.982^{* * * *} \\
(1.339)\end{array}$ \\
\hline Capitalization & $\begin{array}{c}2.697^{* * * *} \\
(0.415)\end{array}$ & $\begin{array}{c}2.716^{* * * * *} \\
(0.429)\end{array}$ & $\begin{array}{c}2.635^{* * * *} \\
(0.420)\end{array}$ & $\begin{array}{c}2.743^{* * * *} \\
(0.424)\end{array}$ & $\begin{array}{c}2.691 \text { **** } \\
(0.409)\end{array}$ & $\begin{array}{c}2.819^{* * * * *} \\
(0.380)\end{array}$ \\
\hline Reinsurance & $\begin{array}{l}-0.198 \\
(0.299)\end{array}$ & $\begin{array}{l}-0.086 \\
(0.297)\end{array}$ & $\begin{array}{l}-0.234 \\
(0.311)\end{array}$ & $\begin{array}{l}-0.238 \\
(0.315)\end{array}$ & $\begin{array}{l}-0.214 \\
(0.297)\end{array}$ & $\begin{array}{c}0.345 \\
(0.277)\end{array}$ \\
\hline Portfolio risk & $\begin{array}{c}0.641 \\
(0.490)\end{array}$ & $\begin{array}{c}0.391 \\
(0.553)\end{array}$ & $\begin{array}{c}0.691 \\
(0.476)\end{array}$ & $\begin{array}{c}0.636 \\
(0.495)\end{array}$ & $\begin{array}{l}0.676 \\
(0.470)\end{array}$ & $\begin{array}{c}0.574 \\
(0.427)\end{array}$ \\
\hline Underwriting risk & $\begin{array}{l}-0.116 \\
(0.123)\end{array}$ & $\begin{array}{l}-0.079 \\
(0.131)\end{array}$ & $\begin{array}{l}-0.140 \\
(0.129)\end{array}$ & $\begin{array}{l}-0.126 \\
(0.129)\end{array}$ & $\begin{array}{l}-0.128 \\
(0.124)\end{array}$ & $\begin{array}{c}-0.221^{* * * *} \\
(0.127)\end{array}$ \\
\hline $\begin{array}{l}\text { Long-tailed } \\
\text { business }\end{array}$ & $\begin{array}{l}0.013 \\
(0.026)\end{array}$ & $\begin{array}{c}0.025 \\
(0.027)\end{array}$ & $\begin{array}{c}0.016 \\
(0.026)\end{array}$ & $\begin{array}{l}0.015 \\
(0.026)\end{array}$ & $\begin{array}{c}0.017 \\
(0.026)\end{array}$ & $\begin{array}{c}0.015 \\
(0.024)\end{array}$ \\
\hline Mutual & $\begin{array}{c}0.633^{* * * *} \\
(0.202)\end{array}$ & $\begin{array}{c}0.662^{* * * *} \\
(0.205)\end{array}$ & $\begin{array}{c}0.611 * * * * \\
(0.203)\end{array}$ & $\begin{array}{c}0.642^{* * * *} \\
(0.205)\end{array}$ & $\begin{array}{c}0.596 * * * * \\
(0.199)\end{array}$ & $\begin{array}{c}0.418^{* * * *} \\
(0.190)\end{array}$ \\
\hline Life insurance & $\begin{array}{c}0.680^{* * * *} \\
(0.206)\end{array}$ & $\begin{array}{c}0.699 * * * \\
(0.214)\end{array}$ & $\begin{array}{c}0.691 * * * * \\
(0.211)\end{array}$ & $\begin{array}{c}0.693 * * * * \\
(0.210)\end{array}$ & $\begin{array}{c}0.613 * * * * \\
(0.208)\end{array}$ & $\begin{array}{c}0.719 * * * \\
(0.206)\end{array}$ \\
\hline $\begin{array}{l}\text { Industry } \\
\text { concentration }\end{array}$ & $\begin{array}{l}-0.001 \\
(0.002)\end{array}$ & $\begin{array}{l}-0.003 \\
(0.003)\end{array}$ & $\begin{array}{c}0.000 \\
(0.002)\end{array}$ & $\begin{array}{c}0.000 \\
(0.002)\end{array}$ & $\begin{array}{c}0.000 \\
(0.002)\end{array}$ & $\begin{array}{l}-0.000 \\
(0.000)\end{array}$ \\
\hline Constant & $\begin{array}{l}-0.046 \\
(1.263)\end{array}$ & $\begin{array}{l}1.192 \\
(1.647)\end{array}$ & $\begin{array}{l}-0.412 \\
(1.316)\end{array}$ & $\begin{array}{l}-0.452 \\
(1.332)\end{array}$ & $\begin{array}{l}-0.128 \\
(1.263)\end{array}$ & $\begin{array}{l}-1.123 \\
(0.972)\end{array}$ \\
\hline Year dummies & Yes & Yes & Yes & Yes & Yes & Yes \\
\hline Clustering level & Firm & Firm & Firm & Firm & Firm & Firm \\
\hline $\begin{array}{l}\text { Number of } \\
\text { observations }\end{array}$ & 1,382 & 1,382 & 1,382 & 1,382 & 1,382 & 1,382 \\
\hline Number of firms & 183 & 183 & 183 & 183 & 183 & 183 \\
\hline$R^{2}$ & $19.47 \%$ & $12.99 \%$ & $18.23 \%$ & $19.33 \%$ & $18.64 \%$ & $32.60 \%$ \\
\hline Adjusted $R^{2}$ & $18.53 \%$ & $11.97 \%$ & $17.27 \%$ & $18.38 \%$ & $17.69 \%$ & $31.81 \%$ \\
\hline F-value & $\begin{array}{c}7.97 \\
(16,182)\end{array}$ & $\begin{array}{c}6.85 \\
(16,182)\end{array}$ & $\begin{array}{c}8.02 \\
(16,182)\end{array}$ & $\begin{array}{c}8.16 \\
(16,182)\end{array}$ & $\begin{array}{c}9.06 \\
(16,182)\end{array}$ & $\begin{array}{c}12.41 \\
(16,182)\end{array}$ \\
\hline
\end{tabular}

Note(s): This table reports the ordinary least squares (OLS) regressions for different $Z$-score measures for the Spanish insurance sector during the period 2010-2017. Zs1 is defined in Equation [3], Zs2 is defined in Equation [4], Zs3 is defined in Equation [5], Zs4 is defined in Equation [6], Zs5 is defined in Equation [7], and Zs6 is defined in Equation [8]. The dependent variable is included in its logarithmic form. See Table 2 for a description of the independent variables. Robust standard errors, which are clustered by firms, are reported in parentheses. Significance levels are indicated as follows: $* * *=$ significance at the 1 percent level, $* *=$ significance at the 5 percent level, and $*=$ significance at the 10 percent level. The explanatory power of the model is highlighted in Italic

by Windmeijer (2005), we employ a two-step estimation procedure with finite-sample corrected standard errors, which provides less biased coefficient estimates and more accurate standard errors. We treat insurer characteristics (except their organizational form and their specialization) as endogenous variables by using suitable instruments for both the equation in levels and the equation in differences [14]. Industry concentration and macroeconomic control variables (i.e. year dummies) are considered strictly exogenous. We verify the validity of the instruments by using Hansen's $J$-test of overidentifying restrictions.

The higher values of the lagged dependent variables (except for the $Z s 2$ regression) confirm the dynamic character of the model specification, indicating strong persistence; i.e. the adjustment of risk is very slow. As expected, the regression coefficients indicate a positive relationship between size and the $Z$-score; i.e. larger firms are less risky than 


\begin{tabular}{lrr}
\hline Variable & The financial & VIF \\
SOundness of & insurance \\
Industry concentration & 6.010 \\
Year 2016 & 3.870 \\
Year 2017 & 3.200 \\
Capitalization & 3.010 \\
Size & 2.480 \\
Life insurance & 2.070 \\
Long-tailed business & 1.830 \\
Year 2015 & 1.740 \\
Year 2011 & 1.560 \\
Year 2012 & 1.370 \\
Year 2014 & 1.360 \\
Underwriting risk & 1.230 \\
Mutual & 1.200 \\
Reinsurance & 1.170 \\
Portfolio risk & 1.150 \\
Profitability & 1.110 \\
Mean VIF & 2.150 \\
Note(s): This table reports the variance inflation factors (VIFs) for the variables included in the $Z$-score & variables included in \\
regressions presented in Table 6. See Table 2 for a description of the variables & the $Z$-score regressions \\
\hline & Table 7. \\
\hline
\end{tabular}

smaller firms, supporting previous findings in the literature (Chen and Wong, 2004; Pasiouras and Gaganis, 2013; Shim, 2017). We demonstrate a strong positive relationship between ROA and the $Z$-score but only when $Z s 6$ is used as the dependent variable. This result supports the hypothesis that highly profitable insurers are less likely to become insolvent because they manage expenses effectively and can set competitive premium rates (Caporale et al., 2017). The relationship with capitalization, as measured by the equity-tototal assets ratio, is positive and statistically significant in all of the analyzed models. This finding corroborates the hypothesis that more capitalized insurers have higher $Z$-scores, in line with Shim (2011) and Altuntas and Rauch (2017). We also report that a greater use of reinsurance may increase the financial soundness of firms; i.e. higher levels of reinsurance result in lower insurer risk by transferring part of this risk to third parties (as found by Alhassan and Biekpe, 2018). However, this result applies only to the $Z s 6$ approach and has low statistical significance. The positive coefficient we find for the dummy that identifies mutual insurance companies is in accordance with the hypothesis that mutual companies are more financially stable than stock insurers because in mutual companies, the policyholders are also the owners of the firms. Therefore, managers' incentives to increase asset risk are lower in mutual companies than in stock firms (Shim, 2017). Similar to Pasiouras and Gaganis (2013), we also find a positive coefficient for the dummy that identifies life insurance companies, corroborating the hypothesis that life insurers are more financially stable than nonlife insurance companies, which may operate as 'risk takers'. The relationship between industrial concentration and the $Z$-score is negative and significant only for the $Z s 6$ approach. This result supports the concentration-fragility view, providing empirical evidence against the tendency toward increasing concentration that the Spanish insurance market is currently experiencing. Finally, we do not find statistical significance for the variables that measure portfolio risk, underwriting risk or whether a business is long-tailed in any of the six models considered.

Once again, we observe that the $Z$-score measure that incorporates the most statistically significant variables in the risk model is the one that combines the current values of ROA and capitalization with the SD of ROA calculated over the full period. 


\begin{tabular}{|c|c|c|c|c|c|c|c|}
\hline \multirow{4}{*}{$\begin{array}{l}\text { EJMBE } \\
31,1\end{array}$} & Variables & $\begin{array}{l}(1) \\
Z s 1\end{array}$ & $\begin{array}{l}(2) \\
Z s 2\end{array}$ & $\begin{array}{l}(3) \\
Z s 3\end{array}$ & $\begin{array}{l}(4) \\
Z s 4\end{array}$ & $\begin{array}{l}(5) \\
Z s 5\end{array}$ & $\begin{array}{l}(6) \\
Z s 6\end{array}$ \\
\hline & $\begin{array}{l}\text { Lagged } \\
\text { dependent }\end{array}$ & $\begin{array}{c}0.581 * * * \\
(0.038)\end{array}$ & $\begin{array}{c}0.229 * * * \\
(0.039)\end{array}$ & $\begin{array}{c}0.666^{* * * *} \\
(0.044)\end{array}$ & $\begin{array}{c}0.615^{* * * *} \\
(0.038)\end{array}$ & $\begin{array}{c}0.647^{* * * *} \\
(0.045)\end{array}$ & $\begin{array}{c}0.749 * * * * \\
(0.059)\end{array}$ \\
\hline & Size & $0.159 * * *$ & $0.186^{* * * *}$ & $0.127 * * *$ & $0.156^{* * * *}$ & $0.126^{* * * *}$ & $0.097^{* * * *}$ \\
\hline & & $(0.056)$ & $(0.071)$ & $(0.044)$ & $(0.056)$ & $(0.048)$ & $(0.019)$ \\
\hline \multirow[t]{27}{*}{34} & Profitability & $2.156^{*}$ & 2.294 & 0.261 & 2.050 & -0.268 & $2.865^{* * * *}$ \\
\hline & & $(1.294)$ & $(1.956)$ & $(1.329)$ & $(1.430)$ & $(1.344)$ & $(0.377)$ \\
\hline & Capitalization & $\begin{array}{c}1.973^{* * * *} \\
(0.486)\end{array}$ & $\begin{array}{c}3.058 * * * * \\
(0.827)\end{array}$ & $\begin{array}{c}1.638 * * * \\
(0.522)\end{array}$ & $\begin{array}{c}1.971 * * * * \\
(0.530)\end{array}$ & $\begin{array}{c}1.714 * * * * \\
(0.529)\end{array}$ & $\begin{array}{c}1.158 * * * * \\
(0.294)\end{array}$ \\
\hline & Reinsurance & 0.009 & -0.247 & -0.141 & -0.086 & -0.096 & $0.138^{*}$ \\
\hline & & $(0.221)$ & $(0.328)$ & $(0.259)$ & $(0.242)$ & $(0.247)$ & $(0.071)$ \\
\hline & Portfolio risk & -0.177 & -0.499 & -0.122 & -0.148 & -0.076 & -0.078 \\
\hline & & $(0.304)$ & $(0.405)$ & $(0.292)$ & $(0.326)$ & $(0.271)$ & $(0.095)$ \\
\hline & Underwriting & -0.050 & 0.041 & 0.003 & -0.022 & -0.065 & -0.023 \\
\hline & & $(0.104)$ & $(0.197)$ & $(0.126)$ & $(0.116)$ & $(0.122)$ & $(0.069)$ \\
\hline & Long-tailed & -0.010 & 0.016 & 0.001 & -0.003 & 0.001 & -0.009 \\
\hline & business & $(0.023)$ & $(0.034)$ & $(0.019)$ & $(0.023)$ & $(0.020)$ & $(0.012)$ \\
\hline & Mutual & $0.249 * *$ & $0.402 * *$ & 0.163 & $0.254^{* *}$ & 0.165 & $0.159 * * * *$ \\
\hline & & $(0.101)$ & $(0.176)$ & $(0.102)$ & $(0.102)$ & $(0.107)$ & $(0.060)$ \\
\hline & Life insurance & $0.358 * *$ & $0.515^{*}$ & 0.242 & $0.334 *$ & 0.266 & $0.245^{* *}$ \\
\hline & & $(0.166)$ & $(0.269)$ & $(0.172)$ & $(0.176)$ & $(0.190)$ & $(0.112)$ \\
\hline & Industry & 0.001 & -0.001 & 0.001 & 0.001 & & $-0.001^{* * * *}$ \\
\hline & concentration & $(0.001)$ & $(0.002)$ & $(0.001)$ & $(0.001)$ & & $(0.000)$ \\
\hline & Constant & -2.687 & $\begin{array}{l}-1.256 \\
(1.658)\end{array}$ & $-2.520 * *$ & $-2.925^{* * *}$ & -1.754 & $-1.220^{* * * *}$ \\
\hline & Year dummies & Yes & Yes & Yes & Yes & Yes & Yes \\
\hline & $z_{1}$ & 36.24 & 5.50 & 30.93 & 35.01 & 31.14 & 31.87 \\
\hline & & $(9,182)$ & $(9,182)$ & $(9,182)$ & $(9,182)$ & $(8,182)$ & $(9,182)$ \\
\hline & $z_{2}$ & $2.29(7,182)$ & $2.67(7,182)$ & $1.75(7,182)$ & $2.15(7,182)$ & $1.48(8,182)$ & $3.84(7,182)$ \\
\hline & $m_{1}$ & -6.84 & -6.71 & -6.94 & -6.87 & -6.86 & -2.06 \\
\hline & $m_{2}$ & -1.18 & 0.17 & -0.75 & -1.12 & -0.75 & 0.85 \\
\hline & Hansen & 169.26 (204) & 165.26 (204) & 161.05 (204) & 167.22 (204) & 163.37 (204) & 174.25 (204) \\
\hline & $\begin{array}{l}\text { Number of } \\
\text { observations }\end{array}$ & 1,382 & 1,382 & 1,382 & 1,382 & 1,382 & 1,382 \\
\hline & Number of firms & 183 & 183 & 183 & 183 & 183 & 183 \\
\hline
\end{tabular}

Note(s): This table presents the determinants of insurer risk in the Spanish insurance sector (2010-2017) according to different $Z$-score measures. $Z s 1$ is defined in Equation [3], Zs2 is defined in Equation [4], Zs3 is defined in Equation [5], Zs4 is defined in Equation [6], Zs5 is defined in Equation [7], and $Z s 6$ is defined in Equation [8]. The dependent variable is included in its logarithmic form. See Table 2 for a description of the independent variables. We use the system-GMM estimator developed by Arellano and Bover (1995) and Blundell and Bond (1998). Except for Mutual, Life insurance, Industry concentration and Year dummies, all variables are considered endogenous in our model. In model (5), Industry concentration is dropped due to collinearity. We report heteroskedasticity-consistent asymptotic standard errors in parentheses, and significance levels are indicated as follows: $* * *=$ significance at the 1 percent level, $* *=$ significance at the 5 percent level, and $*=$ significance at the 10 percent level. $z_{1}$ and $z_{2}$ are Wald tests of the joint significance of the reported coefficients for the continuous and dummy explanatory variables, respectively, asymptotically distributed along an $F$ distribution under the null hypothesis of no significance, with degrees of freedom in parentheses. $m_{i}$ is a serial correlation test of order $i$ using residuals in first differences, asymptotically distributed as $N(0,1)$ under the null hypothesis of no serial correlation. Hansen is a test of the overidentifying restrictions, asymptotically distributed along a $\chi^{2}$ distribution under the null hypothesis of no correlation between the instruments and the error term, with degrees of freedom in parentheses

Table 8.

Determinants of insurer risk in Spain according to the different $Z$-score measures 


\section{Conclusions}

Bearing in mind the increasing relevance of risk supervision in the insurance sector, this paper aims to explore insurers' financial soundness from a wider perspective, considering factors beyond capitalization or the particular event of bankruptcy. The Z-score, which has been widely used in the banking literature, can be considered an appropriate alternative measure of risk and thus a good indicator of the financial soundness of insurance firms. This measure relates the insurer's capital level to variability in its returns, revealing how much variability in returns can be absorbed by capital without the firm becoming insolvent. Higher $Z$-scores are indicative of a higher distance-to-default ratio and thus greater financial soundness.

By comparing six different approaches to calculating the $Z$-score with a final dataset of 183 insurers (1,382 observations) operating in the Spanish insurance sector during the period 2010-2017, we find that the best measure for calculating the $Z$-score is the one that combines current ROA and capitalization values with the SD of ROA calculated over the full period. This approach (i.e. $Z s 6$ ) has the advantage of enable the construction of time-varying $Z$-scores that do not require initial observations to be dropped (Lepetit and Strobel, 2013).

Information provided by the $Z$-score, in addition to that given by more complex risk-based models, may be helpful for microprudential supervision. Moreover, because this indicator uses accounting data, its results are easily verifiable, providing insurance regulators with a better understanding of risk factors for both listed and unlisted insurance companies [15]. Nevertheless, the use of an accounting measure has some disadvantages that need to be considered. First, its reliability depends on the quality of the underlying accounting and auditing framework. Second, the $Z$-score has limitations in the macroprudential monitoring framework because accounting-based measures do not capture systemic risk, although this element may be less relevant in the insurance sector.

\section{Notes}

1. "In order to promote good risk management and align regulatory capital requirements with industry practices, the Solvency Capital Requirement should be determined as the economic capital to be held by insurance and reinsurance undertakings in order to ensure that ruin occurs no more often than once in every 200 cases or, alternatively, that those undertakings will still be in a position, with a probability of at least $99.5 \%$, to meet their obligations to policyholders and beneficiaries over the following 12 months. That economic capital should be calculated on the basis of the true risk profile of those undertakings, taking account of the impact of possible risk-mitigation techniques, as well as diversification effects". [Directive 2009/138/EC of the European Parliament and of the Council of 25 November 2009 on the taking-up and pursuit of the business of insurance and reinsurance (Solvency II) (recast)].

2. Chen and Wong (2004), Sharpe and Stadnik (2007) and Caporale et al. (2017) focus on the particular event of insolvency or bankruptcy and propose models to identify or predict insurers experiencing financial distress. However, researchers undertaking this kind of analysis face the difficulty of finding data on the insolvency of insurance firms - the majority of these companies decide to transfer their business to other insurance firms or to just stop underwriting new business instead of becoming "insolvent" (Caporale et al., 2017).

3. Bongini et al. (2018) test the reliability of seven different versions of the $Z$-score in detecting periods of banking crisis on a sample of 20 Central, Eastern and Southeastern European (CESEE) countries during 1995-2014.

4. However, unlike banks, insurers are not the primary drivers of systemic risk. They are not part of the financial payment system and rarely interact with other insurers (except through reinsurance). This contrasts with banks, as they are primary lenders to other banks and thus are highly interconnected (Rudolph, 2017).

5. The three-year rolling window in the SD calculation avoids the problem that $Z$-scores are exclusively driven by changes in ROA and Eq/TA (Schaeck et al., 2012). Although the use of a
The financial soundness of insurance firms 
EJMBE 31,1

longer period for the calculation of the SD could result in more reliable $Z$-scores, we must consider the loss of observations created by imposing a stronger requirement (Pasiouras and Gaganis, 2013).

6. Gaganis et al. (2019) use this Z-score metric to investigate the interplay between national culture and risk in insurance firms.

7. The database is available at: http://www.dgsfp.mineco.es/es/Entidades/balancesycuentas/Paginas/ Balancescuentasentidadesaseguradoras.aspx

8. This restriction does not apply if we estimate the $Z$-score by combining the values of ROA and capital in current period $t$ with the SD of ROA calculated over the full period (2008-2017). However, because we want to compare different $Z$-score measures, we use the same observations in all of the analyses.

9. We take the natural logarithms of all the $Z$-score measures to control for the skewness exhibited by the original variables (Laeven and Levine, 2009; Liu et al., 2013; Chiaramonte et al., 2016).

10. We use the same criteria as the DGSFP (2018) to differentiate between life and nonlife specialized insurers.

11. The only variable that has a VIF higher than 4 is the HHI, which is used to account for industry concentration (and has a value close to 6). We regress our models with alternative variables (e.g. the concentration ratio CR5) and even without including that variable, each of which leaves our conclusions practically unchanged.

12. Although the explanatory power (as measured by the adjusted $R^{2}$ ) of the risk models considered is not very high, our results are very similar to those found by Shim (2011), Fields et al. (2012), Altuntas and Rauch (2017) and Cummins et al. (2017), among others.

13. This is a required condition to test for the absence of second-order serial correlation.

14. We also estimate regressions in which the organizational form and/or the specialization are considered endogenous variables. The results barely differ from those previously obtained.

15. Plantin and Rochet (2007) state that "prudential ratios should be defined simply and derived from public accounts, because these accounts are easily verifiable".

\section{References}

Alhassan, A.L. and Biekpe, N. (2018), "Competition and risk-taking behaviour in the non-life insurance market in South Africa", The Geneva Papers on Risk and Insurance, Vol. 43, pp. 492-519, doi: 10. 1057/s41288-017-0074-z.

Altuntas, M. and Rauch, J. (2017), "Concentration and financial stability in the property-liability insurance sector: global evidence", The Journal of Risk Finance, Vol. 18, pp. 284-302, doi: 10. 1108/JRF-10-2016-0128.

Arellano, M. and Bover, O. (1995), "Another look at the instrumental variable estimation of errorcomponents models", Journal of Econometrics, Vol. 68, pp. 29-51, doi: 10.1016/0304-4076(94) 01642-D.

Baselga-Pascual, L., Trujillo-Ponce, A. and Cardone-Riportella, C. (2015), "Factors influencing bank risk in Europe: evidence from the financial crisis", North American Journal of Economics and Finance, Vol. 34, pp. 138-166, doi: 10.1016/j.najef.2015.08.004.

Beck, T. and Laeven, L. (2006), Resolution of Failed Banks by Deposit Insurers: Cross-country Evidence. Policy Research Working Paper 3920, World Bank, WA, DC.

Blundell, R. and Bond, S. (1998), "Initial conditions and moment restrictions in dynamic panel data models", Journal of Econometrics, Vol. 87, pp. 115-143, doi: 10.1016/S0304-4076(98)00009-8.

Bongini, P., Iwanicz-Drozdowska, M., Smaga, P. and Witkowski, B. (2018), "In search of a measure of banking sector distress: empirical study of CESEE banking sectors", Risk Management, Vol. 20, pp. 242-257, doi: 10.1057/s41283-017-0031-y. 
Boyd, J.H., De Nicolò, G. and Jalal, A.M. (2006), Bank Risk-Taking and Competition Revisited: New Theory and New Evidence, Working Paper 06/297, International Monetary Fund, WA, DC.

Caporale, G.M., Cerrato, M. and Zhang, X. (2017), "Analysing the determinants of insolvency risk for general insurance firms in the UK", Journal of Banking and Finance, Vol. 84, pp. 107-122, doi: 10. 1016/j.jbankfin.2017.07.011.

Chen, R. and Wong, K.A. (2004), "The determinants of financial health of Asian insurance companies", The Journal of Risk and Insurance, Vol. 71, pp. 469-499, doi: 10.1111/j.0022-4367.2004.00099.x.

Chiaramonte, L., Croci, E. and Poli, F. (2015), "Should we trust the Z-score? Evidence from the European Banking industry”, Global Finance Journal, Vol. 28, pp. 111-131, doi: 10.1016/j.gfj. 2015.02.002.

Chiaramonte, L., Hong, F., Poli, F. and Zhou, M. (2016), "How accurately can Z-score predict bank failure?", Financial Markets, Institutions and Instruments, Vol. 25, pp. 333-360, doi: 10.1111/ fmii.12077.

Čihák, M. (2007), "Systemic loss: a measure of financial stability", Czech Journal of Economics and Finance, Vol. 57, pp. 5-26.

Čihák, M. and Hesse, H. (2010), "Islamic banks and financial stability: an empirical analysis", Journal of Financial Services Research, Vol. 38, pp. 95-113, doi: 10.1007/s10693-010-0089-0.

Cummins, J.D. and Sommer, D.W. (1996), "Capital and risk in property-liability insurance markets", Journal of Banking and Finance, Vol. 20, pp. 1069-1092, doi: 10.1016/0378-4266(95)00044-5.

Cummins, J.D. and Nini, G.P. (2002), "Optimal capital utilization by financial firms: evidence from the property-liability insurance industry", Journal of Financial Services Research, Vol. 21, pp. 15-53, doi: 10.1023/A:1014369617192.

Cummins, J.D., Rubio-Misas, M. and Vencappa, D. (2017), "Competition, efficiency and soundness in European life insurance markets”, Journal of Financial Stability, Vol. 28, pp. 66-78, doi: 10.1016/j. jfs.2016.11.007.

Das, U.S., Davies, N. and Podpiera, R. (2003), Insurance and Issues in Financial Soundness, Working Paper WP/03/138, International Monetary Fund, WA, DC.

De Haan, L. and Kakes, J. (2010), “Are non-risk based capital requirements for insurance companies binding?”, Journal of Banking and Finance, Vol. 34, pp. 1618-1627, doi: 10.1016/j.jbankfin.2010. 03.008.

Delis, M.D. and Staikouras, P.K. (2011), "Supervisory effectiveness and bank risk", Review of Finance, Vol. 15, pp. 511-543, doi: 10.1093/rof/rfq035.

Dirección General de Seguros y Fondos de Pensiones (DGSFP) (2018), Informe 2017 Seguros y Fondos de Pensiones, Ministerio de Industria, Economía y Competitividad.

Eling, M. and Marek, S.D. (2013), "Corporate governance and risk taking: evidence from the U.K. and German insurance markets", The Journal of Risk and Insurance, Vol. 81, pp. 653-682, doi: 10. 1111/j.1539-6975.2012.01510.x.

European Insurance and Occupational Pensions Authority (EIOPA) (2017), "Insurance statistics", available at: https:/eiopa.europa.eu/Pages/Financial-stability-and-crisis-prevention/InsuranceStatistics.aspx.

Fields, L.P., Gupta, M. and Prakash, P. (2012), "Risk taking and performance of public insurers: an international comparison", The Journal of Risk and Insurance, Vol. 79, pp. 931-962, doi: 10.1111/ j.1539-6975.2012.01479.x.

Gaganis, C., Hasan, I., Papadimitri, P. and Tasiou, M. (2019), "National culture and risk-taking: evidence from the insurance industry", Journal of Business Research, Vol. 97, pp. 104-116, doi: 10.1016/j.jbusres.2018.12.037.

Gründl, H., Dong, M.I. and Gal, J. (2016), "The evolution of insurer portfolio investment strategies for long-term investing", OECD Journal: Financial Market Trends, Vol. 1, pp. 1-55, doi: 10.1787/fmt2016-5jln3rh7qf46.

The financial soundness of insurance firms 
EJMBE 31,1

Haiss, P. and Sümegi, K. (2008), "The relationship between insurance and economic growth in Europe: a theoretical and empirical analysis", Empirica, Vol. 35, pp. 405-431, doi: 10.1007/s10663-0089075-2.

Hannan, T.H. and Hanweck, G.A. (1988), "Bank insolvency and the market for large certificates of deposit”, Journal of Money, Credit and Banking, Vol. 20, pp. 203-211, doi: 10.2307/1992111.

Hesse, H. and Čihák, M. (2007), Cooperative Banks and Financial Stability, Working Paper 07/2, International Monetary Fund, WA, DC.

Ho, C.-L., Lai, G.C. and Lee, J.P. (2013), "Organizational structure, board composition, and risk taking in the U.S. Property casualty insurance industry", The Journal of Risk and Insurance, Vol. 80, pp. 169-203, doi: 10.1111/j.1539-6975.2012.01464.x.

Hu, J.-L. and Yu, H.-E. (2014), "Risk management in life insurance companies: evidence from Taiwan”, North American Journal of Economics and Finance, Vol. 29, pp. 185-199, doi: 10.1016/j.najef. 2014.06.012.

International Monetary Fund (IMF) (2017), Spain Financial Sector Assessment Program Technical Note- Insurance Sector Supervision and Regulation, Country Report 17/338, International Monetary Fund, WA, DC.

Khan, M.S., Scheule, H. and Wu, E. (2017), "Funding liquidity and bank risk taking", Journal of Banking and Finance, Vol. 82, pp. 203-216, doi: 10.1016/j.jbankfin.2016.09.005.

Laeven, L. and Levine, R. (2009), "Bank governance, regulation and risk taking”, Journal of Financial Economics, Vol. 93, pp. 259-275, doi: 10.1016/j.jfineco.2008.09.003.

Laeven, L. and Majnoni, G. (2003), "Loan loss provisioning and economic slowdowns: too much, too late?", Journal of Financial Intermediation, Vol. 12, pp. 178-197, doi: 10.1016/S1042-9573(03) 00016-0.

Lepetit, L. and Strobel, F. (2013), "Bank insolvency risk and time-varying Z-score measures", Journal of International Financial Markets, Institutions and Money, Vol. 25, pp. 73-87, doi: 10.1016/j. intfin.2013.01.004.

Li, X., Tripe, D. and Malone, C. (2017), "Measuring bank risk: an exploration of Z-score”, Social Science Research Network (SSRN), pp. 1-38, doi: 10.2139/ssrn.2823946.

Liu, H., Molyneux, P. and Wilson, J.O.S. (2013), "Competition and stability in European banking: a regional analysis”, The Manchester School, Vol. 81, pp. 176-201, doi: 10.1111/j.1467-9957.2011. 02285.x.

Maechler, A., Mitra, S. and Worrell, D. (2010), "Decomposing financial risks and vulnerabilities in Eastern Europe", IMF Economic Review, Vol. 57, pp. 25-60, doi: 10.1057/imfsp.2009.31.

Mankaï, S. and Belgacem, A. (2016), "Interactions between risk taking, capital and reinsurance for property-liability insurance firms", Journal of Risk and Insurance, Vol. 83, pp. 1007-1043, doi: 10. 1111/jori.12080.

MAPFRE Economic Research (2018), “The Spanish insurance market in 2017”, available at https:// www.fundacionmapfre.org/documentacion/publico/i18n/catalogo_imagenes/grupo.cmd? path $=1098241$.

Moreno, I., Parrado-Martínez, P. and Trujillo-Ponce, A. (2020), "Economic crisis and determinants of solvency in the insurance sector: new evidence from Spain", Accounting and Finance, Vol. 60 No. 3, pp. 2965-2994, doi: 10.1111/acfi.12422.

Pasiouras, F. and Gaganis, C. (2013), "Regulations and soundness of insurance firms: international evidence”, Journal of Business Research, Vol. 66, pp. 632-642, doi: 10.1016/j.jbusres.2012.09.023.

Pavić, T., Miletić, M. and Koźul, R. (2019), "Financial stability of insurance companies in selected CEE countries", Business System Research, Vol. 10 No. 2, pp. 163-178, doi: 10.2478/bsrj-2019-025.

Plantin, G. and Rochet, J.-C. (2007), When Insurers Go Bust: An Economic Analysis of the Role and Design of Prudential Regulation, Princeton University Press, New Jersey, NJ. 
Rubio-Misas, M. (2020), "Ownership structure and financial stability: evidence from Takaful and conventional insurance firms", Pacific-Basin Finance Journal, Vol. 62, p. 101355, doi: 10.1016/j. pacfin.2020.101355.

Rubio-Misas, M. and Fernandez-Moreno, M. (2017), "Solvency surveillance and financial crisis: evidence from the Spanish insurance industry", Spanish Journal of Finance and Accounting, Vol. 46, pp. 272-297, doi: 10.1080/02102412.2017.1291167.

Rudolph, M.J. (2017), Reviewing Systemic Risk within the Insurance Industry, Society of Actuaries, IL.

Schaeck, K., Cihak, M., Maechler, A. and Stolz, S. (2012), "Who disciplines bank managers", Review of Finance, Vol. 16, pp. 197-243, doi: 10.1093/rof/rfr010.

Sharpe, I.G. and Stadnik, A. (2007), "Financial distress in Australian general insurers", The Journal of Risk and Insurance, Vol. 74, pp. 377-399, doi: 10.1111/j.1539-6975.2007.00217.x.

Shim, J. (2011), "Mergers and Acquisitions, diversification and performance in the U.S. propertyliability insurance industry", Journal of Financial Services Research, Vol. 39, pp. 119-144, doi: 10. 1007/s10693-010-0094-3.

Shim, J. (2017), "An investigation of market concentration and financial stability in property-liability insurance industry", The Journal of Risk and Insurance, Vol. 84, pp. 567-597, doi: 10.1111/ jori.12091.

Shiu, Y.M. (2011), "Reinsurance and capital structure: evidence from the United Kingdom non-life insurance industry", The Journal of Risk and Insurance, Vol. 78, pp. 475-494, doi: 10.1111/j.15396975.2010.01387.x.

Strobel, F. (2011), "Bank insolvency risk and Z-score measures with unimodal returns", Applied Economics Letters, Vol. 18, pp. 1683-1685, doi: 10.1080/13504851.2011.558474.

Windmeijer, F. (2005), "A finite sample correction for the variance of linear efficient GMM estimators", Journal of Econometrics, Vol. 126, pp. 25-51, doi: 10.1016/j.jeconom.2004.02.005.

Yeyati, E.L. and Micco, A. (2007), "Concentration and foreign penetration in Latin American banking sectors: impact on competition and risk", Journal of Banking and Finance, Vol. 31, pp. 1633-1647, doi: 10.1016/j.jbankfin.2006.11.003.

\section{Corresponding author}

Antonio Trujillo-Ponce can be contacted at: atrupon@upo.es

For instructions on how to order reprints of this article, please visit our website:

www.emeraldgrouppublishing.com/licensing/reprints.htm

Or contact us for further details: permissions@emeraldinsight.com
The financial soundness of insurance firms 